\title{
Influence of Paclobutrazol on Growth and Yield of Jamun cv. Chintamani
}

\author{
Swathi Hegde, J. Dinakara Adiga*, M.K. Honnabyraiah, \\ T.R. Guruprasad, M. Shivanna and G.K. Halesh
}

Department of Fruit Science, College of Horticulture, GKVK campus, Bengaluru, Karnataka, India

*Corresponding author

\begin{abstract}
A B S T R A C T
Keywords

Grwth and yield, Jamun, Cultivation, fruit

Article Info

Accepted:

12 December 2017

Available Online:

10 January 2018

Jamun (Syzygium cumini Skeels.) is an important minor indigenous fruit of India belonging to the family Myrtaceae. Jamun cultivation is constrained with the problem of irregular bearing which leads to considerable loss of their production potential. Paclobutrazol a triazole derivative has been effectively used to induce and manipulate flowering, fruiting and tree vigor in several perennial fruit crops. An investigation was taken up at Regional Horticultural Research and Extension Centre (RHREC), University of Horticultural Sciences Campus, Gandhi Krishi Vignana Kendra, Bengaluru, during 2016-17 to exploit the possibility of regularizing the flowering using paclobutrazol (PBZ). The six year old grafted plants of jamun $c v$ Chintamani were applied with $0.5,1.0,1.5,2.0,2.5$ and $3.0 \mathrm{~g}$ a.i of PBZ per plant through soil. The control plants did not receive PBZ treatment. The application of PBZ at $3.0 \mathrm{~g}$ a.i./ plant resulted less increment in plant height $(23.67 \mathrm{~cm})$ and canopy spread in N-S $(38.50 \mathrm{~cm})$ and E-W $(50.83 \mathrm{~cm})$ direction, $2.5 \mathrm{~g} \mathrm{a.i} /$ plant resulted in highest number (424) of panicles per plant, number of flowers per panicle (51.33) and length of flowering panicle $(16.16 \mathrm{~cm})$. The study revealed that PBZ at $1.5 \mathrm{~g}$ a.i/ plant resulted in highest number (292) of new flushes per plant which ultimately led to highest fruit number (4217) and fruit yield per plant $(47.13 \mathrm{~kg})$.
\end{abstract}

\section{Introduction}

Jamun (Syzygium cumini Skeels.) is an important minor indigenous fruit of India belongs to the family Myrtaceae. It has gained the major importance as an arid zone horticultural crop because of its hardy nature and high yielding potential. It is widely grown in many parts of India from the Indo-Gangetic plains in the North to Tamil Nadu in the South (Singh and Srivastava, 2000). Jamun is widely used worldwide in the treatment of diabetes by the traditional practitioners over many centuries and its various plant parts possess many pharmacological properties. Not only it has wonderful anti hyperglycemic properties, but it has also proven antioxidant, antibacterial, antigen toxic, anti-inflammatory and anti-HIV properties (Sagrawat et al., 2006). The plant is rich in compounds containing anthocyanins, glucoside, ellagic acid, isoquercetin, kaemferol and myrecetin. The seeds are claimed to contain alkaloid, jambosine, and glycoside jambolin or 
antimellin (Swamy et al., 2012). Flowering and fruiting takes place in March- April and bear fruits from May to July. Inflorescences are borne in leaf axils of branchlets. Flowers are bisexual and light yellow in colour. Some jamun varieties have a second season in October. Jamun is cross pollinated tree. It is observed that fruit drop in jamun starts just after fruit set and continues up to maturity. Only $15-30 \%$ fruits reach maturity. The flower and fruit drop are found at three stages. The first drop takes place during bloom or shortly thereafter, this proves to be the harvest drop as about $52 \%$ of the flowers drop off after four weeks from flowering.

Jamun cultivation is constrained with the problem of irregular bearing or cropping periodicity as well as staggered or erratic flowering behaviour which leads to considerable loss of their production potential. Paclobutrazol (PBZ), a triazole derivative, has been effectively used to induce and manipulate flowering, fruiting and tree vigour in several perennial fruit crops. Soil application of paclobutrazol has been effective in promoting flowering and increasing yield in many fruit crops.

Besides reducing gibberellins level, PBZ increases cytokinin contents, root activity and $\mathrm{C}$ : $\mathrm{N}$ ratio. PBZ also affects microbial population and dehydrogenase activity in soil. PBZ has been characterized as an environmentally stable compound in soil and water environments with a half-life of more than a year under both aerobic and anaerobic conditions.

The present investigation was carried at Regional Horticultural Research and Extension Centre (RHREC), University of Horticultural Sciences Campus, Gandhi Krishi Vignana Kendra, Bengaluru, during 2016-17 to exploit the possibility of regularizing the flowering using paclobutrazol (PBZ).

\section{Materials and Methods}

The experiment was conducted in the year of 2016 using 6 year old trees of Chintamani cultivar of Jamun maintained at Regional Horticulture Research and Extension Centre, Bengaluru, College of Horticulture, GKVK, Bengaluru, Karnataka. The orchard was well planned with a spacing of $6 \mathrm{~m} \times 6 \mathrm{~m}$.

The experimental design was laid out in a Randomized Complete Block Design (RCBD) with 7 treatment 3 replications. Paclobutrazol (Lustar 30\% W/V) was applied as a soil drench at concentrations of $0,0.5,1.0,1.5$, 2.0, 2.5, $3.0 \mathrm{~g}$ a.i. (gram active ingredient) per plant. The treatment was imposed at the time of emergence of new flush. The PBZ (Lustar $30 \% \mathrm{~W} / \mathrm{V})$ at required concentration was dissolved in the water and applied to soil in 15 $\mathrm{cm}$ deep trench at $60 \mathrm{~cm}$ away from the plant trunk and covered with soil. Soil moisture was maintained for two months for better absorption of the chemical.

Observation on plant height, Girth of the stem below graft union, Girth of the stem above graft union, Canopy spread, Number of new flushes, Inter nodal length, Number of panicles per plant, Length of the flowering panicle, Width of the flowering panicle, Number of flowers per panicle, yield per plant were recorded. The plant height was measured vertically from the ground to tip of the tree and expressed in centimetre. Girth of the stem was measured below and above the graft union at a distance of $30 \mathrm{~cm}$ from the union. Canopy spread was measured in two directions in North-South and East-West directions. Numbers of new flushes were counted in all four directions of plant and mean of them was expressed as the number of flushes. The internodal length was measured vertically from the base to the tip of new shoot and recorded in centimetres. Mean internodal length was calculated by measuring internodal 
length of twenty shoots in all the directions of the tree. Numbers of new emerged panicles were counted in all four directions of plant and was expressed as the number of new flushes. Length and width of the flowering panicles were measured in all the directions. Mean length and width of flowering panicle was calculated by measuring the length and width of twenty panicles in all the directions of the tree.

\section{Results and Discussion}

\section{Increment in plant height}

Plant height was significantly influenced by the application of PBZ in jamun $\mathrm{cV}$ Chintamani (Table 1). Among different levels of application, PBZ @ $3.0 \mathrm{~g}$ a.i. recorded significantly least increment in plant height $(23.67 \mathrm{~cm})$ and it was on par with $2.5 \mathrm{~g}$ a.i. $(25.00 \mathrm{~cm})$ and $2.0 \mathrm{~g}$ a.i. $(26.50 \mathrm{~cm})$. The maximum increase in plant height $(34.50 \mathrm{~cm})$ was recorded in control. Per cent decrease in plant height for PBZ treated plants over control was maximum in plants treated with $3.0 \mathrm{~g}$ a.i. (31.39 \%) followed by $2.5 \mathrm{~g}$ a.i. (27.54\%), $2.0 \mathrm{~g}$ a.i. (23.19\%) (Fig. 1). The reduction in plant height with the use of paclobutrazol might be due to the inhibitory effect of paclobutrazol on gibberellins biosynthesis pathway at the sub-apical meristem, which ultimately reduced cell elongation, rate of cell division and decreased the shoot growth.

Inhibition in gibberellins activity following check in the conversion of ent-kaurene to entkaurenoic acid in the gibberellins biosynthetic pathway has been attributed as the possible primary mechanism by which paclobutrazol restricts the vegetative growth. Similar results were reported by Quinlan and Webster (1982) in plums and cherries, Teferi et al., (2010) in Tommy Atkins mango, Tandel and Patel (2011) in mango.
Increase in canopy spread in North- South and East-West direction

Plant spread in North-South direction was influenced by the application of PBZ in jamun cv Chintamani (Table 1). Among different levels of application, PBZ @ $3.0 \mathrm{~g}$ a.i. recorded least increment in spread in NorthSouth direction $(50.83 \mathrm{~cm})$ and it was on par with $2.5 \mathrm{~g}$ a.i. $(51.17 \mathrm{~cm}), 1.5 \mathrm{~g}$ a.i. $(51.50 \mathrm{~cm})$ and $2.0 \mathrm{~g}$ a.i. $(52.67 \mathrm{~cm})$. The maximum increment in the plant spread in North- South direction was recorded in control $(58.33 \mathrm{~cm})$.

Plant spread in East-West direction was significantly reduced by the application of PBZ in jamun cv Chintamani. Among different levels of application, PBZ @ $3.0 \mathrm{~g}$ a.i. recorded significantly least increment in spread in East-West direction $(38.50 \mathrm{~cm})$ and it was on par with $2.5 \mathrm{~g}$ a.i. $(39.83 \mathrm{~cm}), 1.5 \mathrm{~g}$ a.i. $(42.33 \mathrm{~cm})$ and $2.0 \mathrm{~g}$ a.i. $(43.00 \mathrm{~cm})$.

The maximum increase in plant spread in East-West direction was recorded in control $(49.00 \mathrm{~cm})$. Per cent decrease in plant spread in N-S direction for PBZ treated plants over control was maximum in plants treated with $3.0 \mathrm{~g}$ a.i. (12.86 \%) followed by $2.5 \mathrm{~g}$ a.i. (12.27\%), $1.5 \mathrm{~g}$ a.i. (9.70 \%).

Per cent decrease in plant spread in E-W direction for PBZ treated plants over control was maximum in plants treated with $3.0 \mathrm{~g}$ a.i. (21.43\%) followed by $2.5 \mathrm{~g}$ a.i. (18.71\%), 1.5 g a.i. (13.61\%) (Fig. 1). The reduced canopy spread might be due to reduced vegetative growth through reduction in cell elongation and internodes extension ultimately retarding plant growth by via inhibition of gibberellins biosynthesis in the presence of paclobutrazol which ultimately reduce the canopy spread. Similar results were reported by Quinlan and Richardson (1984) in plums and cherries, Teferi et al., (2010) in Tommy Atkins mango, Meena et al., (2014) in cashew. 


\section{Stem thickness above and below the graft union}

The data related to stem thickness above and below graft union in different treatments were recorded in jamun cv. Chintamani (Table 1). The present trend indicates that PBZ has no role in altering the girth of the plants. The process of cell division (secondary growth) is associated with increment in stem girth. Since PBZ has little or no role to play in cell division, stem girth was not influenced by PBZ application. Similar results were reported by Assem (1986) in Roumi red grapes, Blanco (1988) in peach and nectarine and Meena et al., (2014) in cashew.

\section{Internodal length}

Internodal length was significantly influenced by the application of PBZ in jamun $\mathrm{cV}$ Chintamani (Table 2). Among different levels of application, PBZ @ $2.0 \mathrm{~g}$ a.i. recorded significantly lesser internodal length $(1.77 \mathrm{~cm})$ and it was on par with $2.5 \mathrm{~g}$ a.i. $(1.93 \mathrm{~cm}), 3.0$ $\mathrm{g}$ a.i. $(1.97 \mathrm{~cm})$ and $1.5 \mathrm{~g}$ a.i. $(2.20 \mathrm{~cm})$.

The highest internodal length was recorded in control $(3.17 \mathrm{~cm})$. Per cent decrease in internodal length for PBZ treated plants over control was maximum in plants treated with $1.5 \mathrm{~g}$ a.i. (44.16 \%) followed by $2.5 \mathrm{~g}$ a.i. (39.12\%), $3.0 \mathrm{~g}$ a.i. (37.85 \%) (Fig. 2).

One of the main roles of gibberellins in trees is the stimulation of cell elongation. When gibberellin production is inhibited, cell division still occurs, but the new cells do not elongate.

This results in production of shoots with the same numbers of leaves and internodes compressed into a shorter internodal length. Similar results were reported by Khurshid et al., (1997) in Braebum apple and Nafeez et al., (2010) in mango.

\section{Number of new flushes}

The application of PBZ significantly influenced the number of new flushes in jamun cv. Chintamani (Table 2). Among different levels of application, PBZ @ $1.5 \mathrm{~g}$ a.i. recorded significantly higher number of new flushes (292.00) and it was on par with $3.0 \mathrm{~g}$ a.i. (276.67) and $2.0 \mathrm{~g}$ a.i. (264.00).

The minimum numbers of new flushes were recorded in control (175.33). Per cent increase in new flushes for PBZ treated plants over control is maximum in plants treated with 1.5 $\mathrm{g}$ a.i. (66.54\%) followed by $3.0 \mathrm{~g}$ a.i. (57.80 $\%), 2.0 \mathrm{~g}$ a.i. (50.57\%) (Fig. 3). Increase in new flush might be due to increased activity of auxin-like substances, higher starch reserve, total carbohydrates and higher $\mathrm{C}: \mathrm{N}$ ratio in the shoots (Yeshitela et al., 2004). According to Kurian and Iyer (1992) paclobutrazol can enhance the total phenolic content of terminal buds and alter the phloem to xylem ratio of the stem, which is important in restricting the vegetative growth and enhancing flushes by increasing the bud sprout, by altering assimilate partitioning and patterns of nutrient supply for new growth which is supporting for increasing the number of flushes per plant.

\section{Leaf area}

The leaf area was significantly influenced by the application of PBZ in jamun cV. Chintamani (Table 2). The higher leaf area was recorded in control $\left(64.64 \mathrm{~cm}^{2}\right)$. Among the different levels of PBZ, PBZ @ $3.0 \mathrm{~g}$ a.i. recorded least leaf area $\left(33.47 \mathrm{~cm}^{2}\right)$ and it was on par with $2.5 \mathrm{~g}$ a.i. $\left(36.15 \mathrm{~cm}^{2}\right)$. Reduction in gibberellins synthesis leads to reduced cell elongation which in turn reduces the leaf area but exhibited thicker epicuticular wax layers, larger epidermal cells, a single layer of large spongy mesophyl tissue and thickness of leaves. Similar results were reported by Teferi et al., (2010) in Tommy Atkins mango. 
Table.1 Effects of PBZ on extent of vegetative growth parameters in jamun $c v$. Chintamani

\begin{tabular}{|c|c|c|c|c|c|}
\hline Treatment & $\begin{array}{l}\text { Increment } \\
\text { in plant } \\
\text { height }(\mathrm{cm})\end{array}$ & $\begin{array}{l}\text { Increase in } \\
\text { plant } \\
\text { spread in } \mathrm{N} \text { - } \\
\mathrm{S} \text { direction } \\
\text { (cm) }\end{array}$ & $\begin{array}{l}\text { Increase in } \\
\text { plant spread } \\
\text { in E-W } \\
\text { direction } \\
\text { (cm) }\end{array}$ & $\begin{array}{l}\text { Stem } \\
\text { thickness } \\
\text { above graft } \\
\text { union }(\mathrm{cm})\end{array}$ & $\begin{array}{c}\text { Stem } \\
\text { thickness } \\
\text { below graft } \\
\text { union }(\mathrm{cm})\end{array}$ \\
\hline $\mathrm{T}_{1}$ : Control (no PBZ application) & 34.50 & 58.33 & 49.00 & 51.13 & 68.50 \\
\hline $\mathrm{T}_{2}: \mathrm{PBZ}$ application at $0.5 \mathrm{~g}$ a.i./plant & 32.33 & 57.17 & 48.00 & 49.50 & 69.07 \\
\hline $\mathrm{T}_{3}: \mathrm{PBZ}$ application at $1.0 \mathrm{~g}$ a.i./plant & 30.33 & 55.83 & 44.50 & 50.90 & 67.80 \\
\hline $\mathrm{T}_{4}: \mathrm{PBZ}$ application at $1.5 \mathrm{~g}$ a.i./plant & 29.67 & 51.50 & 42.33 & 50.43 & 70.43 \\
\hline $\mathrm{T}_{5}: \mathrm{PBZ}$ application at $2.0 \mathrm{~g}$ a.i./plant & 26.50 & 52.67 & 43.00 & 47.43 & 65.20 \\
\hline $\mathrm{T}_{6}: \mathrm{PBZ}$ application at $2.5 \mathrm{~g}$ a.i./plant & 25.00 & 51.17 & 39.83 & 53.53 & 70.47 \\
\hline $\mathrm{T}_{7}: \mathrm{PBZ}$ application at $3.0 \mathrm{~g}$ a.i./plant & 23.67 & 50.83 & 38.50 & 46.30 & 65.67 \\
\hline S.Em \pm & 0.95 & 1.42 & 1.86 & 3.11 & 1.72 \\
\hline CD@ $9 \%$ & 2.92 & 4.39 & 5.72 & NS & NS \\
\hline
\end{tabular}

Table.2 Effect of PBZ on internodal length, number of new flushes and leaf area in jamun $c v$. Chintamani

\begin{tabular}{|c|c|c|c|}
\hline Treatment & $\begin{array}{l}\text { Inter nodal } \\
\text { length (cm) }\end{array}$ & $\begin{array}{c}\text { Number of new } \\
\text { flushes }\end{array}$ & Leaf area $\left(\mathrm{cm}^{2}\right)$ \\
\hline $\mathrm{T}_{1}$ : Control (no PBZ application) & 3.17 & 175.33 & 64.64 \\
\hline $\mathrm{T}_{2}:$ PBZ application at $0.5 \mathrm{~g}$ a.i./plant & 2.83 & 226.67 & 56.09 \\
\hline $\mathrm{T}_{3}: \mathrm{PBZ}$ application at $1.0 \mathrm{~g}$ a.i./plant & 2.33 & 239.67 & 54.03 \\
\hline $\mathrm{T}_{4}: \mathrm{PBZ}$ application at $1.5 \mathrm{~g}$ a.i./plant & 2.20 & 292.00 & 46.22 \\
\hline T 5: PBZ application at $2.0 \mathrm{~g}$ a.i./plant & 1.77 & 264.00 & 39.98 \\
\hline $\mathrm{T}_{6}: \mathrm{PBZ}$ application at $2.5 \mathrm{~g}$ a.i./plant & 1.93 & 232.00 & 36.15 \\
\hline $\mathrm{T}_{7}: \mathrm{PBZ}$ application at $3.0 \mathrm{~g}$ a.i./plant & 1.97 & 276.67 & 33.47 \\
\hline S.Em \pm & 0.17 & 14.45 & 1.06 \\
\hline CD@ 5\% & 0.54 & 44.51 & 3.27 \\
\hline
\end{tabular}

Table.3 Effect of PBZ on flowering and yield in jamun $c v$. Chintamani

\begin{tabular}{|l|}
\hline \multicolumn{1}{|c|}{ Treatment } \\
\hline $\mathrm{T}_{1}:$ Control (no PBZ application) \\
\hline $\mathrm{T}_{2}:$ PBZ application at $0.5 \mathrm{~g}$ a.i./plant \\
\hline $\mathrm{T}_{3}: \mathrm{PBZ}$ application at $1.0 \mathrm{~g}$ a.i./plant \\
\hline $\mathrm{T}_{4}: \mathrm{PBZ}$ application at $1.5 \mathrm{~g}$ a.i./plant \\
\hline $\mathrm{T}_{5}: \mathrm{PBZ}$ application at $\mathbf{2 . 0} \mathrm{g}$ a.i./plant \\
\hline $\mathrm{T}_{6}: \mathrm{PBZ}$ application at $\mathbf{2 . 5} \mathrm{g}$ a.i./plant \\
\hline $\mathrm{T}_{7}: \mathrm{PBZ}$ application at $\mathbf{3 . 0} \mathrm{g}$ a.i./plant \\
\hline $\mathrm{S} . \mathrm{Em} \pm$ \\
\hline $\mathrm{CD} 5 \%$ \\
\hline
\end{tabular}

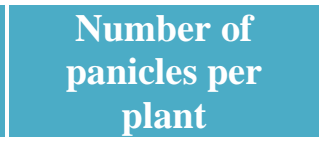

plant

\begin{tabular}{|c|}
\hline 136.33 \\
\hline 302.33 \\
\hline 318.00 \\
\hline 336.67 \\
\hline 417.67 \\
\hline 423.67 \\
\hline 314.67 \\
\hline 33.28 \\
\hline 102.54 \\
\hline
\end{tabular}

Number of
flowers per
panicle

\begin{abstract}
35.33
\end{abstract}
38.33

45.33

49.00

51.33

51.33

47.67

3.55

10.94

\section{Length of the flowering panicle $(\mathbf{c m})$}

\begin{tabular}{|l}
11.33 \\
12.07 \\
12.57 \\
13.17 \\
15.70 \\
16.17 \\
15.10 \\
1.05 \\
3.24
\end{tabular}

11.33

9.43

11.37

11.83

12.63

11.70

13.27

0.75

2.31 
Table.4 Effect of PBZ on yield parameters in jamun $c v$. Chintamani

Treatment

\section{$\mathrm{T}_{1}$ : Control (no PBZ application) \\ $\mathrm{T}_{2}:$ PBZ application at $0.5 \mathrm{~g}$ a.i./plant \\ $\mathrm{T}_{3}$ : PBZ application at $1.0 \mathrm{~g}$ a.i./plant \\ $\mathrm{T}_{4}$ : PBZ application at $1.5 \mathrm{~g}$ a.i./plant \\ $\mathrm{T}_{5}$ : PBZ application at $2.0 \mathrm{~g}$ a.i./plant \\ $\mathrm{T}_{6}: \mathrm{PBZ}$ application at $2.5 \mathrm{~g}$ a.i./plant \\ $\mathrm{T}_{7}$ : PBZ application at $3.0 \mathrm{~g}$ a.i./plant}

S.Em \pm

CD@ 5\%

\section{Fruit set per}

panicle$$
25.00
$$

30.33

30.67

37.67

40.00

39.33

36.00

2.84

8.74

\section{Fruit number per} plant

1984.00

3062.00

3014.33

4217.67

3824.33

3851.00

2532.00

358.17

1103.62
Yield per plant (kg)

22.59

30.13

31.14

47.13

43.34

46.37

27.45

4.38

13.51

Fig.1 Percent decrease in plant height and plant spread in PBZ treated plants over control

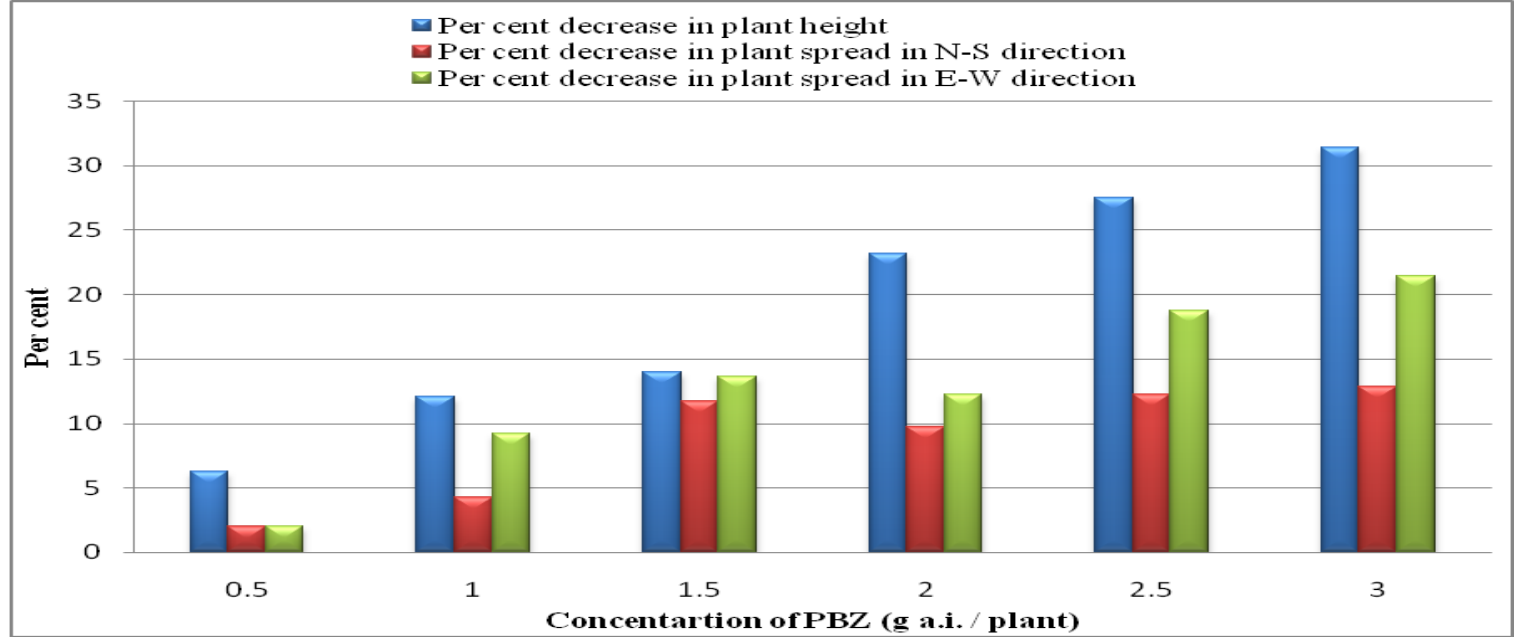

Fig.2 Percent decrease in internodal length in PBZ treated plants over control

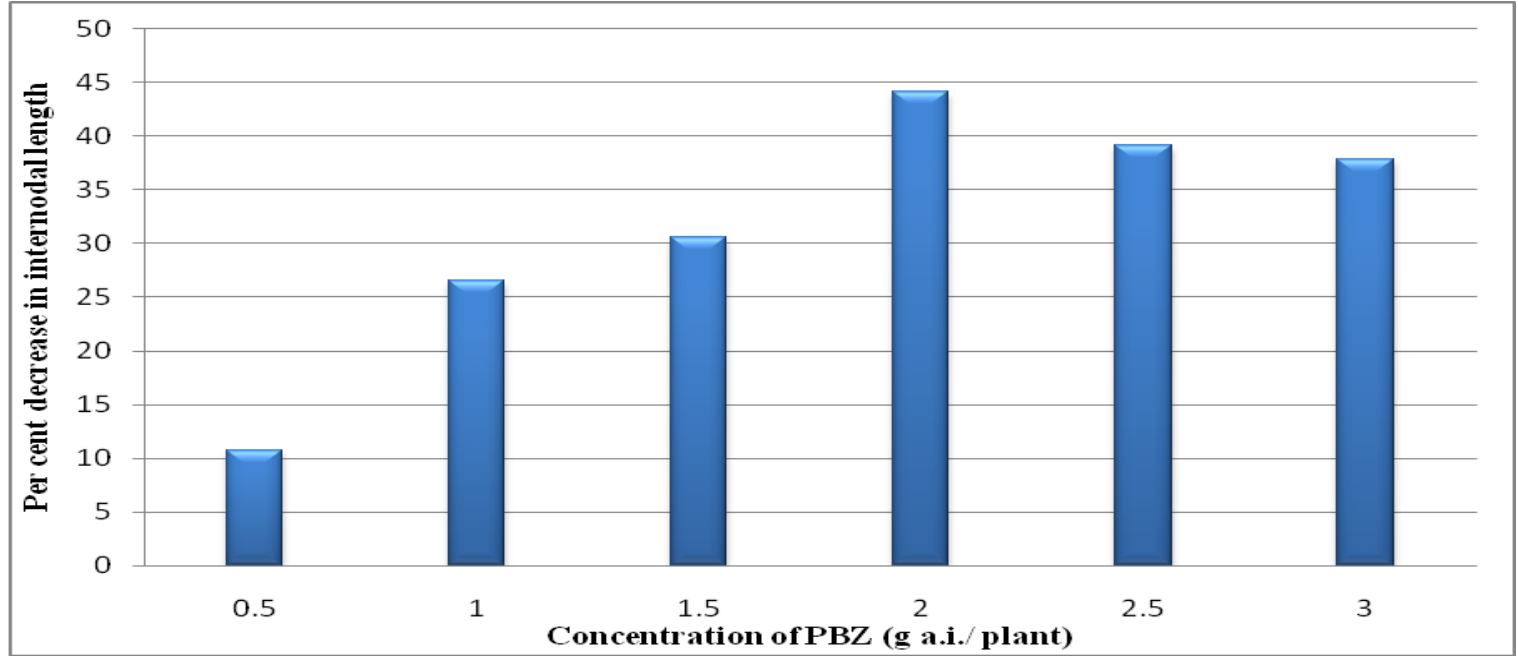


Fig.3 Percent increase in new flushes in PBZ treated plants over control

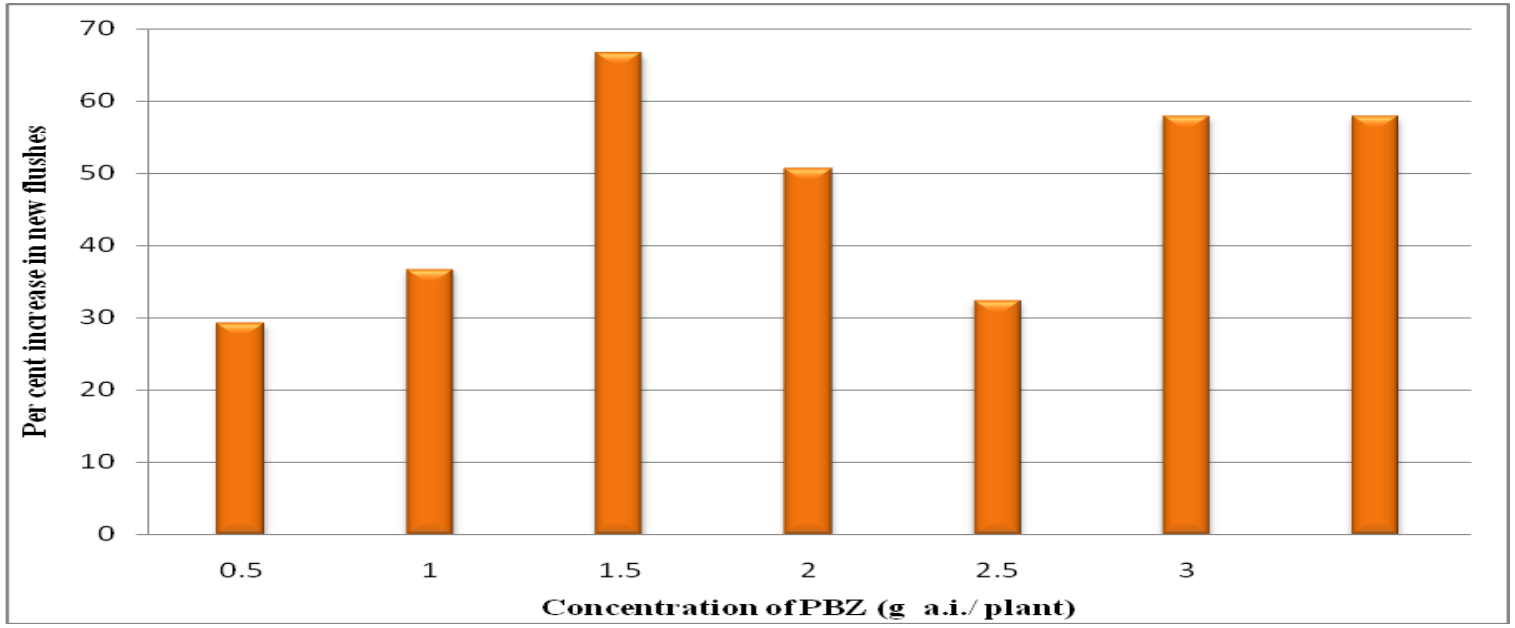

Fig.4 Percent increase in number of panicles per plant in PBZ treated plants over control

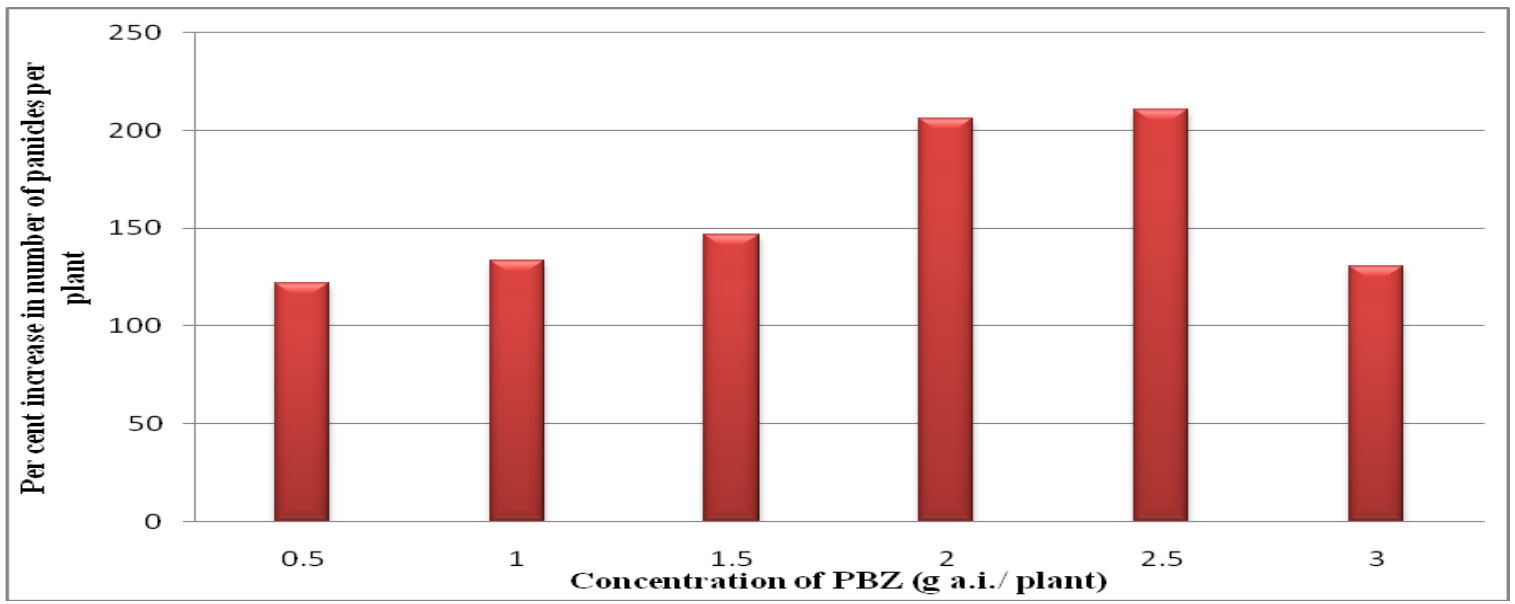

Fig.5 Percent increase in fruit set per panicle in PBZ treated plants over control

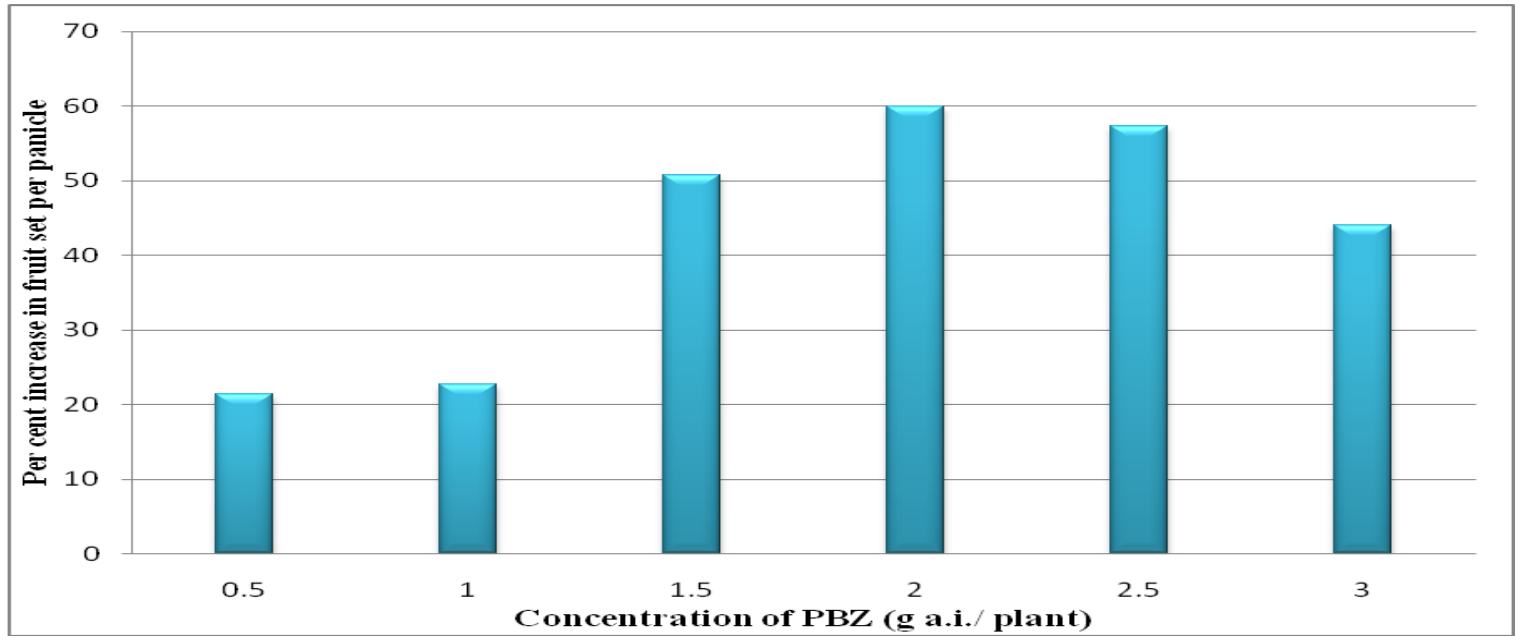


Fig.6 Percent increase in yield per plant in PBZ treated plants over control

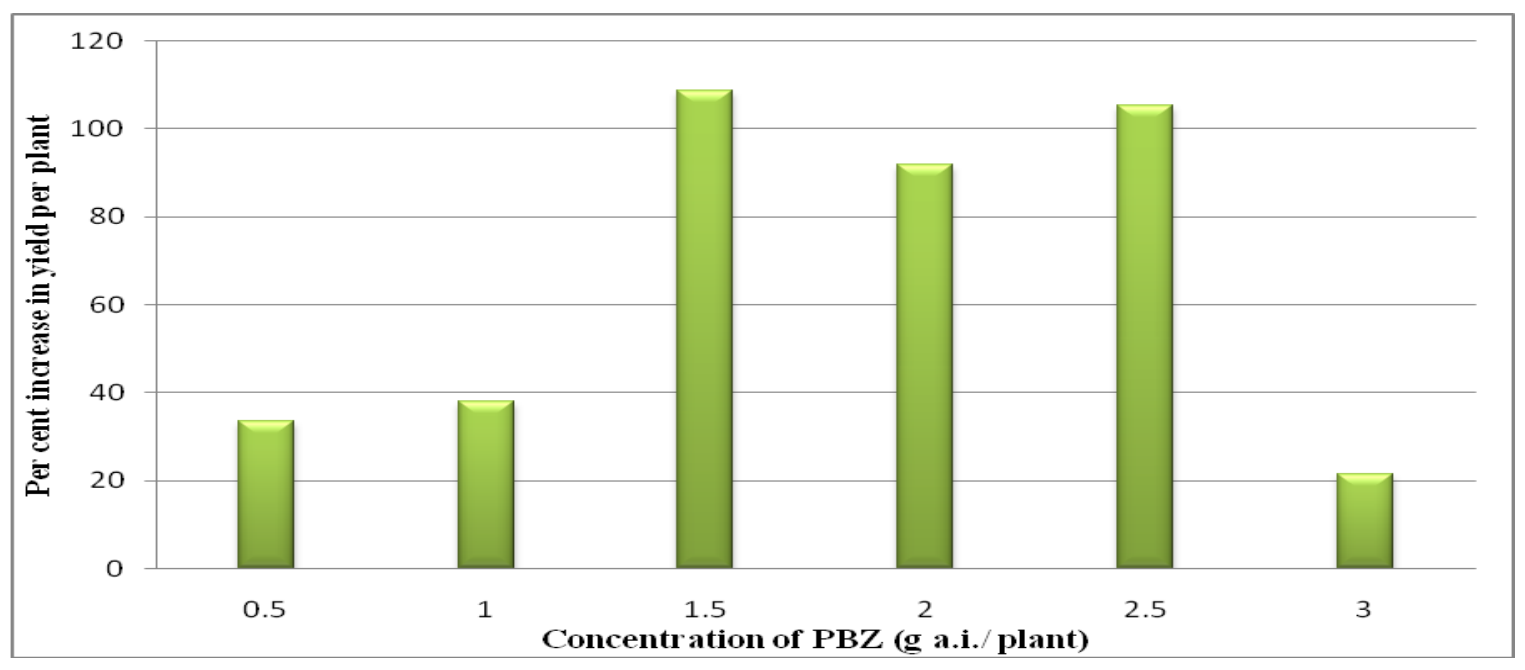

Number of panicles per plant

Number of panicles per plant was significantly influenced by the application of PBZ in jamun cv. Chintamani (Table 3). Among different levels of application, PBZ @ $2.5 \mathrm{~g}$ a.i. (423.67) recorded the highest number of panicles per plant and it was on par with $2.0 \mathrm{~g}$ a.i. (417.67) and $1.5 \mathrm{~g}$ a.i. (336.67). The least number of panicles per plant was recorded in control (136.33). Per cent increase in panicles per plant for PBZ treated plants over control was maximum in plants treated with $2.5 \mathrm{~g}$ a.i. (210.77\%) followed by $2.0 \mathrm{~g}$ a.i. (206.37\%), 1.5 g a.i. (146.95\%) (Fig. 4). The reason might be due to suppression of vegetative growth by PBZ which could have led to enhancement of total phenol content of terminal buds and altered the xylem to phloem ratio of the stem, which in turn altered the assimilate partitioning more towards reproductive shoots. Similar results were reported by Anusuya and Selvarajan (2014) in mango and Jasmine et al., (2011) in mango.

\section{Number of flowers per panicle}

The application of PBZ significantly influenced the number of flowers per panicle in jamun cv. Chintamani during 2015-16 (Table 3). Among different levels of application, PBZ @ 2.5 g a.i. (51.33) and 2.0 $\mathrm{g}$ a.i. (51.33) recorded the highest number of flowers per panicle which were on par with $1.5 \mathrm{~g}$ a.i. (49.00). The lowest number of flowers per panicle was recorded in control (35.33). This may be due to the higher $\mathrm{C}: \mathrm{N}$ ratio in shoots on account of treatment of paclobutrazol, suggesting that paclobutrazol promotes flowering by increasing starch accumulation as reported by Protacio, et al., (2000) in Carabao and Yeshitela, et al., 2004 in Tommy Atkins.

\section{Length of flowering panicle}

The length of flowering panicle was significantly influenced by the application of PBZ in jamun cv. Chintamani (Table 3). Among different levels of application, PBZ @ $2.5 \mathrm{~g}$ a.i. $(16.17 \mathrm{~cm})$ recorded highest length of flowering panicle and it was on par with $2.0 \mathrm{~g}$ a.i. $(15.70 \mathrm{~cm}), 3.0 \mathrm{~g}$ a.i. $(15.10 \mathrm{~cm})$ and $1.5 \mathrm{~g}$ a.i. $(13.17 \mathrm{~cm})$. The least length of flowering panicle was recorded in control $(11.33 \mathrm{~cm})$. The reason might be due to reduced vegetative growth leading to diversion of reserved carbohydrates towards the reproductive growth i.e towards the developing panicle. Similar results were reported by Nafeez et al., (2010) in mango, Jasmine et al., (2011) in mango. 


\section{Width of flowering panicle}

The width of flowering panicle was significantly influenced by the application of PBZ in jamun cv. Chintamani (Table 3). Among different levels of application, PBZ @ $3.0 \mathrm{~g}$ a.i. $(13.27 \mathrm{~cm})$ recorded highest width of flowering panicle and it was on par with $2.0 \mathrm{~g}$ a.i. $(12.63 \mathrm{~cm}), 1.5 \mathrm{~g}$ a.i. $(11.83 \mathrm{~cm}), 2.5$ $\mathrm{g}$ a.i. $(11.70 \mathrm{~cm})$ and $1.0 \mathrm{~g}$ a.i. $(11.37 \mathrm{~cm})$. The least width of flowering panicle was recorded in $0.5 \mathrm{~g}$ a.i. $(9.43 \mathrm{~cm})$ which is on par with control $(10.33 \mathrm{~cm})$. This might be due to the changes in hormonal concentrations in the PBZ treated trees leading to diversion of reserved carbohydrates towards the reproductive growth. Similar results were reported by Nafeez et al., (2010) in mango, Jasmine et al., (2011) in mango.

\section{Fruit set per panicle}

The fruit set per panicle was significantly influenced by the application of PBZ in jamun cv. Chintamani (Table 4). Among different levels of application, PBZ @ $2.0 \mathrm{~g}$ a.i. (40.00) resulted in highest number of fruit set per panicle and it was on par with $2.5 \mathrm{~g}$ a.i. (39.33), $1.5 \mathrm{~g}$ a.i. (37.67) and $3.0 \mathrm{~g}$ a.i. (36.00). The fruit set per panicle was least in control (25.00). Per cent increase in fruit set per panicle for PBZ treated plants over control was maximum in plants treated with $2.0 \mathrm{~g}$ a.i. (60.00\%) followed by $2.5 \mathrm{~g}$ a.i. (57.32\%), $1.5 \mathrm{~g}$ a.i. (50.68 \%) (Fig. 5). This may be due to the reason that PBZ which has been reported to alter source and sink relationship and exert influence on partitioning the photosynthates to the sites of flowering and fruit production with a reduction in vegetative growth. Similar results were reported by Kurian et al., (2001) in mango, Lina and Protacio (2015) in jackfruit.

\section{Fruit number per plant}

The fruit number per plant was significantly influenced by the application of PBZ in jamun cv. Chintamani (Table 4). Among different levels of application, PBZ @ $1.5 \mathrm{~g}$ a.i. (4216.67) resulted in highest fruit number per plant and it was on par with $2.5 \mathrm{~g}$ a.i. (3851.00) and $2.0 \mathrm{~g}$ a.i. (3824.00). The minimum fruit number per plant was recorded in control (1984). This might be due to significantly higher fruit set in the paclobutrazol treated plants which had a favourable impact on culminating in to higher fruit number per plant. In this context, Kurian et al., (2001) reported that paclobutrazol appeared to favourably alter the source sink relationship of mango to support fruit growth with a reduction in vegetative growth.

\section{Yield per plant $(\mathrm{kg} /$ plant $)$}

Yield per plant was significantly influenced by the application of PBZ in jamun cv. Chintamani (Table 4). Among different levels of application, PBZ @ $1.5 \mathrm{~g}$ a.i. (47.13 $\mathrm{kg} /$ plant) resulted in highest yield per plant and it was on par with $2.5 \mathrm{~g}$ a.i. (46.37 $\mathrm{kg} /$ plant) and $2.0 \mathrm{~g}$ a.i. (43.34 kg/plant). The lowest yield per plant was recorded in control $(22.59 \mathrm{~kg} /$ plant). Per cent increase in yield per plants for PBZ treated plants over control was maximum in plants treated with $1.5 \mathrm{~g}$ a.i. (108.63\%) followed by $2.5 \mathrm{~g}$ a.i. (105.27\%), $2.0 \mathrm{~g}$ a.i. (91.85 \%) (Fig. 6). This may be due to high flowering intensity which resulted in higher fruit number, more number of fruits/plant which ultimately increased fruit yield in PBZ treated plants. Similar results were reported by Anusuya and Selvarajan (2014) in Alphonso mango, Jasmine et al., (2011) in mango.

Use of hormones in fruit production became a new paradigm. Soil application of Paclobutrazol at pre- flushing stage of jamun plants was found to be effective in reducing the plant height, canopy spread, intermodal length and yield increment per plant over control. 


\section{References}

Anusuya, P. and Selvarajan, M., 2014. Effect of dose and time of paclobutrazol application on physiology of flowering and yield in mango (Mangifera indica L.) cultivar Alphonso. Trends in Biosciences, 7(12): 1213-1216.

Assem, D.S., 1986. Effect of pre-bloom spray and soil applied to paclobutrazol on in Roumi red grapes. Hort sci., 21(3): 178.

Blanco, A., 1988. Control of shoot growth of peach and nectarine trees with paclobutrazol. J. Hort. Sci., 63: 201-207.

Jasmine, A.J., Nainar, P., Kennedy, R. R., Paramaguru, P. and Balasubramanyan, S., 2011. Regulation for off season flowering and fruiting habit in mango with paclobutrazol. The Asian J. Hort., 6 (2): 538-539.

Khurshid, T., Mcneil, D.L. and Trought, M.C.T., 1997. Effect of foliar- applied gibberellins and soil- applied paclobutrazol on reproductive and vegetative growth of Braebum apple trees growing under a high- density planting system. New Zealand J. Crop Hortl. Sci., 25: 49-58.

Kurian, R. M. and Iyer, C.P.A., 1993. Stem anatomical characteristics in relation to tree vigour in mango (Mangifera indica L.). Sci. Hort., 50: 245-253.

Kurian, R.M., Reddy, Y.T.N., Sonkar, R.K. and Reddy, P.P., 2001. Effect of paclobutrazol on source-sink relationship in mango (Mangifera indica L.). J. Appl. Hort., 3 (2): 88-90.

Lina, D.P. and Protacio, C.M., 2015. Phenology of jackfruit (Artocarpus heterophyllus lam.) and effects of paclobutrazol on off-season fruit production. Acta Hort. 1088: 495-500.

Meena, R.K., Adiga, J.D., Nayak, M.G., Saroj, P. L. and Kalaivanan, D., 2014. Effect of Paclobutrazol on growth and yield of cashew (Anacardium occidentale L.). Indian Society Pl. Res., 27(1): 11-16.

Nafeez, M., Faqueer, M., Ahmad, S., Alam khan, M., Jamil, M. and Naveed Aslam, M., 2010. Paclobutrazol soil drenching supresses vegetative growth, reduces malformation and increases production in mango. Int. $J$. Fruit Sci., 10: 431-440.

Protacio, C., Cunjate, R., Quinto, J., Molinyawe, G. and Paelmo, G., 2000. Regulation of flowering in Carabao mango trees by paclobutrazol. Philippine. J. Crop Sci., 25: 14.

Quinlan, J.D. and Richardson, P. J., 1984. Effect of paclobutrazol $\left(\mathrm{PP}_{333}\right)$ on apple shoots growth. Acta Hort., 146: 105-111.

Quinlan, J.D. and Webster, A.D., 1982. Effect of the growth retardant PP333 on growth of plums and cherries. Int. Society Hort. Sci., 1: 1071.

Sagrawat, H., Mann, A.S. and Kharya, M. D., 2006. Pharmacological potential of Eugenia jambolana. Pharmacog Mag., 6(2): 96-105.

Singh, E.S. and Srivastava, A.K., 2000. Genetic diversity - Jamun (Syzygium cumini Skeels). Indian J. Hort., 45 (3): 2.

Tandel, Y.N. and Patel, N.L., 2011. Effect of chemicals on growth, yield and economics of mango (Mangifera indica L.). Karnataka J. Agric. Sci., 24 (3): 362-365.

Teferi, Y., Robbertse, P.J. and Stassen, P. J. C., 2010. Paclobutrazol suppressed vegetative growth and improved yield as well as fruit quality of Tommy Atkins mango (Mangifera indica L.) in Ethiopia. New Zealand J. Crop. Hort. Sci., 32 (3): 281293.

Yeshitela, T., Robbertse, P.J. and Stassen, P.J.C., 2004. Paclobutrazol suppressed vegetative growth and improved yield as well as fruit quality of 'Tommy Atkins' mango (Mangifera indica) in Ethiopia. New Zealand J. Crop Hort. Sci., 32:281-293.

\section{How to cite this article:}

Swathi Hegde, J. Dinakara Adiga, M.K. Honnabyraiah, T.R. Guruprasad, M. Shivanna and Halesh, G.K. 2018. Influence of Paclobutrazol on Growth and Yield of Jamun cv. Chintamani. Int.J.Curr.Microbiol.App.Sci. 7(01): 1590-1599. doi: https://doi.org/10.20546/ijcmas.2018.701.193 